\title{
100 years of Palaeobiodiversity and Palaeoenvironments
}

\author{
P. Königshof ${ }^{1}$ (])
}

Published online: 3 March 2020

(C) The Author(s) 2020

The year 1919 brought widespread changes around the world and a large number of politically motivated strikes and uprisings that took place. On the other hand the League of Nations was established in order to resolve international disputes, but prevented Germany from joining the League of Nations at that time. The year 1919 was the birth of Germany's first democracy. German women voted for the first time - in an election that was to play a pivotal role in the country's history. On February 6, 1919, the National Assembly met in the town of Weimar and formed the Weimar Coalition. They also elected Friedrich Ebert as President of the Weimar Republic. It was the beginning of the interwar times when politicians tried to put the wheel of history into reverse but they finally failed. The world was a different place in those days, but, 100 years later, some things remain the same. Peace is enjoyed by many. Another constant is the journal you are currently reading. And that's a cause for celebration, reflection and gratitude - to the global research community and its evolving needs that have helped to shape and guide us, down through the decades, into what we are today.

Anniversaries are first and foremost an opportunity to reflect. In the first century of its history (1817-1917) the Senckenberg Society for Nature Research (SGN) published three journals: Museum Senckenbergianum (1834-1845), the scientific monograph series Abhandlungen (since 1834) and an annual report Bericht der SGN. In the year 1914 the Johann Wolfgang Goethe-University in Frankfurt was founded. The Senckenberg Society for Nature Research was one of the donors and contributed three Institutes: Zoology, Geology/ Palaeontology, and Minerology. Accordingly, the heads of the Senckenberg departments, Prof. Dr. Otto zur Strassen, Prof. Dr. Martin Moebius and later Prof. Dr. Fritz

\section{P. Königshof}

peter.koenigshof@senckenberg.de

1 Senckenberg - Research Institute and Natural History Museum Frankfurt, Senckenberganlage 25, 60225 Frankfurt am Main, Germany
Drevermann received a professorship. In a next step the SGN decided to launch a scientific journal.

The name of our journal has changed throughout the past century as well as the journal's scientific topics. In 1919 the first issue of Senckenbergiana edited by the SGN appeared in print (Fig. 1) including a wide range of disciplines such as ecology, palaeontology and minerology (e.g. Richter 1919, Schneiderhöhn 1919; Andersson-Stensiö 1919) which reflected the close collaboration with the Johann Wolfgang Goethe-University. The first paper in volume 1 (for 2018) was published by Rudolf and Emma Richter on trilobites (Richter and Richter 1919). Since its first issue, the journal fundamentally increased the scientific collections in a way that a huge number of specimens described in the journal were donated and stored in the scientific collections. From the very first beginning, the journal published a number of landmark papers and became a forum for disseminating primary research findings in different scientific fields. Due to the Second World War tragedy publication was suspended between volume 26, in 1943, and volume 27 (no. 1/3), in September 1946.

But much of what lies between the covers has changed with the times, with evolving science and with publishing technology. Consequently, the publication strategy of the SGN changed in response to the growth of natural science and Senckenbergiana became successor journals. Senckenbergiana continued by Senckenbergiana biologica (1954-2008) and Senckenbergiana lethaea with Volume 35, in May and August 1954, respectively. In 1969 a third series, Senckenbergiana maritima (1969-2008; since 2009 it is published as Marine Biodiversity), was established. Senckenbergiana biologica and Senckenbergiana lethaea continued the volume number series. The importance of the so-called Senckenbergianen for the research community was later also recognized by funding agencies and Senckenberg journals received long-term funding by the German Science Foundation (DFG).

As time and science have moved on and funding was not provided anymore by third parties SGN has decided to reorganise its journals once again in 2008. With 

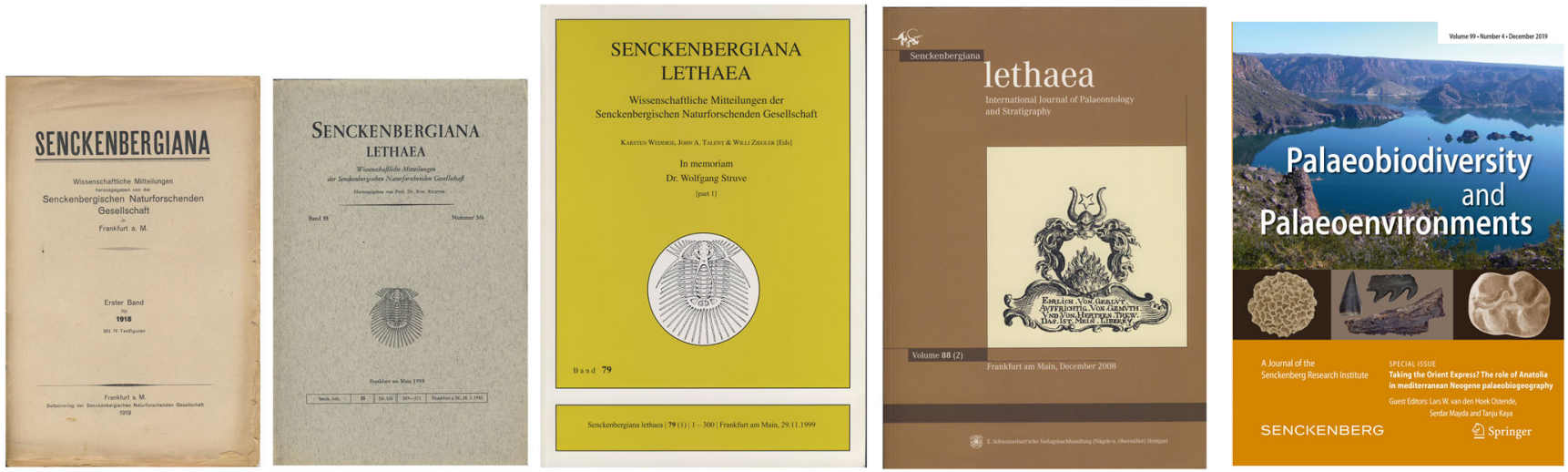

Fig. 1 From Senckenbergiana to Palaeobiodiversity and Palaeoenvironments. 100 years of evolution of the journals' scientific focus, layout and corporate design. Pictures from left to right: The first Senckenbergiana published in 1919. Senckenbergiana lethaea was established in 1954 in response to the growth of natural science, 1955 volume 35(5/6) is pictured here. Changing layout and format in 1993,

Volume 89 (2009) Senckenbergiana lethaea changed its name to Palaeobiodiversity and Palaeoenvironments (Fig. 1) published now by Springer. From 2010 this journal publishes four issues each year providing a multidisciplinary approach in the fields of palaeobiodiversity, palaeoenvironments, and palaeobiogeography in Earth History with a special focus on the knowledge of organisms. By doing this, the journal has gained more international recognition (e.g. increasing number of Special Issues), although Senckenbergiana lethaea has always had an international focus.

In the recent decades competition among scientific journals has grown, as expressed by the impact factor. The present impact factor is 1.07 and 100 years after its first issue the journal has achieved a remarkable position in the frame of other palaeontological journals. This honours the founders of the journal who had an outstanding vision by launching Senckenbergiana as their periodical. However, the rapid evolution of our science and accompanying diversification and specialization should not obscure the large picture. Geoscientists study the complex "Earth system" in order to get a better understanding of individual components such as fossils as well as the system as a whole. Basic science requires fundamental knowledge on organisms independently whether the studied organisms are "sexy" enough and/ or useful for applied sciences. Scientific collections around the world are of outstanding importance in that respect. The search for fundamental knowledge, motivated by interest and curiosity (basic science), is as useful as the search for solutions to specific problems (applied science). Misunderstandings also arise from the frequent assumption that advocates of the utility of basic science which is supposed to lead to applied research, which in turn leads to industrial development and then to pictured here 1999 volume 79(1), special issue in memoriam of Dr. Wolfgang Struve. The last volume of Senckenbergiana lethaea 88(2) in 2008 before it was replaced by the new title Palaeobiodiversity and Palaeoenvironments in 2009, pictured here 2019 volume 99(4) special issue "Taking the Orient Express? The role of Anatolia in mediterranean Neogene palaeobiogeography"

products. While there are many cases in which this has happened, it is also easy to find examples of advances in technology which have led to advances in basic science. The reasons we know much on climate changes in the past - much more than we did 100 years ago, is based on the detailed study of organisms of the past and present in combination of an improved methodology (e.g. geochemical methods). It is known that alpha taxonomy remains one of the fundamental bases for any investigation of the evolution of life on Earth. On the other hand, the ongoing decline in research and expertise in that special field over the last decade in palaeontology jeopardizes future macroevolutionary and biostratigraphic studies (Motteqiun et al. 2017).

Looking forward is also an important aspect of any anniversary celebration. Thus, we should continue to foster interdisciplinary research, and consider how science's role in broader society has changed. We should consider how we can best continue to evolve with the research community and its needs and should share our results with the scientific community worldwide. However, it is for the public benefit and decision makers to increase knowledge on biodiversity dynamics in the Deep Earth. Not only can much be learned by looking at the observational evidence from Earth's past, but such knowledge can provide context for example for current and future climate changes.

Finally, on behalf of Senckenberg Society for Nature Research, I would like to express our sincere thanks to all contributing authors over the last century, an incredible number of reviewers, Editors-in-Chief, Publisher and last not least the German Science Foundation (DFG) for financial support over a long period.

Frankfurt am Main, March 2020. 
Funding Information Open Access funding provided by Projekt DEAL.

Open Access This article is licensed under a Creative Commons Attribution 4.0 International License, which permits use, sharing, adaptation, distribution and reproduction in any medium or format, as long as you give appropriate credit to the original author(s) and the source, provide a link to the Creative Commons licence, and indicate if changes were made. The images or other third party material in this article are included in the article's Creative Commons licence, unless indicated otherwise in a credit line to the material. If material is not included in the article's Creative Commons licence and your intended use is not permitted by statutory regulation or exceeds the permitted use, you will need to obtain permission directly from the copyright holder. To view a copy of this licence, visit http://creativecommons.org/licenses/by/4.0/.

\section{References}

Andersson-Stensiö, E. (1919). Einige Bemerkungen über die systematische Stellung von Saurichthys mougeoti Agassiz. Senckenbergiana Band 1, Nr. 6, 177-187.
Mottequin, B., Slavik, L. and Königshof, P. (eds.) (2017) Increasing knowledge on biodiversity patterns and climate changes in Earth's history by international cooperation: Introduction to the proceedings IGCP 596/SDS Meeting Brussels (2015). In: Mottequin, B., Slavik, L. \& Königshof, P. (eds.) Climate change and biodiversity patterns in the mid-Palaeozoic - Proceedings-Volume IGCP 596/SDS Meeting Brussels (2015). Palaeobiodiversity and Palaeo-environments, 97(3), 367-374. .https://doi.org/10.1007/ s12549-017-296-x.

Richter, R. (1919). Zur Färbung fossiler Brachiopoden. Senckenbergiana Band 1, Nr. 3, 83-96.

Richter, R. \& Richter E. (1919). Der Proetiden-Zweig ASTYCORYPHETROPODOCORYPHE-PTEROPARIA. Senckenbergiana Band 1, Nr. 1, 1-17.

Schneiderhöhn, H. (1919). Mineralogische Beobachtungen in den Kupfer-. Blei-, Zink- und Vanadium-Lagerstätten des Otaviberglandes, Südwestafrika. Senckenbergiana Band 1, Nr. 5, $152-158$.

Publisher's note Springer Nature remains neutral with regard to jurisdictional claims in published maps and institutional affiliations. 